\title{
Holocene valley aggradation driven by river mouth progradation: examples from Australia
}

\author{
Paul Rustomji, ${ }^{1,2, *}$ Jon Olley ${ }^{2}$ and John Chappell ${ }^{1}$ \\ Research School of Earth Sciences, Australian National University, 0200, A.C.T., Australia \\ ${ }^{2}$ CSIRO Land and Water, GPO Box 1666, Canberra, 2601, A.C.T., Australia
}

* Correspondence to: Paul Rustomji, CSIRO Land and Water, GPO Box 1666 , Canberra, 2601, A.C.T., Australia.

E-mail: paul.rustomji@csiro.au
Received 6 June 2005;

Revised II January 2006;

Accepted 20 January 2006

\begin{abstract}
Since the end of the post-glacial sea level rise 6800 years ago, progradation of river mouths into estuaries has been a global phenomenon. The responses of upstream alluvial river reaches to this progradation have received little attention. Here, the links between river mouth progradation and Holocene valley aggradation are examined for the Macdonald and Tuross Rivers in south-eastern Australia. Optical and radiocarbon dating of floodplain sediments indicates that since the mid-Holocene sea level highstand 6800 years ago vertical floodplain aggradation along the two valleys has generally been consistent with the rate at which each river prograded into its estuary. This link between river mouth progradation and alluvial aggradation drove floodplain aggradation for many tens of kilometres upstream of the estuarine limits. Both rivers have abandoned their main Holocene floodplains over the last 2000 years and their channels have contracted. A regional shift to smaller floods is inferred to be responsible for this change, though a greater relative sea level fall experienced by the Macdonald River since the mid-Holocene sea level highstand appears to have been an additional influence upon floodplain evolution in this valley. Copyright @ 2006 John Wiley \& Sons, Ltd.
\end{abstract}

Keywords: progradation; estuary; floodplain; Australia

\section{Introduction}

Progradation of river mouths into estuaries has been widespread since the post-glacial sea level rise ceased approximately 6800 years ago (Stanley and Warne, 1994), producing the extensive alluvial plains that surround the lower reaches of the world's largest rivers (Hori et al., 2001; Goodbred and Kuehl, 2000; Ta et al., 2002). Smaller rivers show comparable features (Young et al., 1996; Dabrio et al., 1999; Kayan, 1999; Dabrio et al., 2000). Well developed facies models exist to describe both the infilling of estuarine embayments and formation of prograding river deltas over the post-glacial period (Dalrymple et al., 1992). The link between river mouth progradation and the evolution of upstream fluvial environments has received less attention. Here, the relationship between Holocene river mouth progradation and upstream river adjustment is examined for two rivers in south-eastern Australia. A basic tenet of fluvial geomorphology is that rivers evolve towards a condition where the sediment load and transport capacity along their length are balanced. Sediment transport capacity $\left(Q_{\mathrm{s}}\right)$ can be expressed as

$$
Q_{\mathrm{s}}=k \frac{Q^{1 \cdot 4} S^{1 \cdot 3}}{\omega W^{0.4}}
$$

where $k$ is a constant representing sediment characteristics, hydraulic roughness and other physical constants, $Q$ is discharge, $S$ is the energy gradient, commonly approximated by the bed gradient, $W$ is channel width and $\omega$ is the particle settling velocity (Yang, 1973). Thus, an increased input of sediment to a reach can be accommodated by increasing discharge and/or energy gradient, or by decreasing channel width (and, to maintain continuity, increasing channel depth). In the context of this study, discharge and the sediment characteristics are imposed from upstream, leaving adjustments of channel width and energy gradient as potential mechanisms for maintaining fluvial equilibrium. 
Within wave dominated estuaries, river mouth progradation typically occurs through deposition of sand and gravel bars at the head of the estuary, forming a low gradient, prograded toe (Dalrymple et al., 1992; Roy et al., 2001). For a river to transport its load across this reach the energy gradient must be maintained. Decreases in channel width are limited, as associated increases in channel depth are restricted by sea level. To maintain gradient, the river bed and floodplain along the prograded reach must aggrade and this aggradation propagates upstream. Unless channel dimensions change, the aggradation induced by a given progradation distance $L$ is given by $L S$. This model is tested using data from the Macdonald and Tuross rivers by investigating whether the timing and rate of alluvial aggradation observed above each river's estuary is consistent with the timing and rate of river mouth progradation.

\section{Study Sites}

The Macdonald and Tuross Rivers (Figure 1(A)), like others along the south-eastern Australian coast, have steep, bedrock-dominated headwaters grading downstream to fully alluvial reaches flanked by floodplains, before finally flowing to estuaries formed in drowned bedrock embayments (Roy et al., 1980, 2001). These estuaries have proven to be highly efficient sediment traps during sea level highstands, with terrestrial sediment delivered to the estuary deposited in deltaic complexes formed as river mouths prograded coastwards over the Hslocene (Roy and Thom, 1981; Nichol et al., 1997; Umitsu et al., 2001). Most estuaries along this coast are still infilling and very few currently deliver substantial amounts of sediment to the continental shelf (Roy, 1977; Roy et al., 2001).

The Macdonald River, with a catchment area of $1920 \mathrm{~km}^{2}$, joins the much larger, drowned river valley estuary of the Hawkesbury River $60 \mathrm{~km}$ upriver of the coast (Figure 1(B) and (C)). The Tuross River, with a catchment area of $2150 \mathrm{~km}^{2}$, flows into a smaller estuary with a lake impounded by a coastal sand barrier (Figure 1(D)). Distances upriver are measured upstream of the Hawkesbury confluence for the Macdonald River and upstream of the coastal barrier for the Tuross River and are denoted as river kilometres (rkm).

The Macdonald River flows south to the Hawkesbury River through a narrow valley in the quartzose Triassic sandstones of the Sydney Basin. The valley floor is rarely more than $2 \mathrm{~km}$ wide and long sections are less than $300 \mathrm{~m}$ wide. The river has a sand bed for the lower $100 \mathrm{rkm}(S=0.0006 \mathrm{~m} / \mathrm{m})$. Figure 2 shows the long profile of the Macdonald River. A lower gradient mixed mud and sand estuarine reach occurs downstream of $14 \mathrm{rkm}$. The maximum tidal range at the Macdonald-Hawkesbury confluence is $1.0 \mathrm{~m}$. Large floods are typically $1000-2000 \mathrm{~m}^{3} \mathrm{~s}^{-1}$ and a series of large ungauged floods occurred between 1949 and 1955 (Erskine, 1986). These floods straightened and widened the channel bed from approximately 20 to $80 \mathrm{~m}$ above the estuarine reach (Henry, 1977; Erskine, 1986). Sediment liberated from this bank erosion contributed to $2 \mathrm{~m}$ of bed aggradation and the intersection of the thalweg with mean sea level shifted $7 \mathrm{~km}$ downstream (Rustomji, 2003). Apart from some localized clearing, the vegetation of the lower Hawkesbury region is broadly similar today to that observed in Holocene pollen records (Dodson and Thom, 1992).

The catchment of the Tuross River comprises Palaeozoic meta-sediments and granites with high points rising over $1000 \mathrm{~m}$ above sea level. The river flows through a bedrock gorge as it leaves the Great Dividing Range and relief decreases coastwards. The study reach extends from the coastal barrier upstream to a bedrock bar in the channel at $59 \mathrm{rkm}$. Bedrock valley walls, typically 200-400 $\mathrm{m}$ apart along the upper section of the study reach and widening to $3 \mathrm{~km}$ in the estuary, confine the channel and floodplains. Figure 3 shows the long profile of the Tuross River. The river bed changes downstream along the study reach from cobbles $\left(S=0.0011 \mathrm{~m} \mathrm{~m}^{-1}\right)$ to sand $\left(S=0.0007 \mathrm{~m} \mathrm{~m}^{-1}\right)$ and then to mixed sand and mud in the estuary. Discontinuous floodplain pockets along the study reach predominantly comprise vertically accreted sandy sediments except in the estuary where laterally accreted floodplains occur (Ferguson and Brierley, 1999a). The maximum tidal range in Tuross Lake is $1.5 \mathrm{~m}$. Floods on the Tuross are roughly twice as large as on the Macdonald. The catchment remains extensively forested though with cleared floodplains.

Lambeck and Nakada (1990) estimate that the two rivers have experienced different mid-Holocene sea level highstands. For the Moruya River (near the Tuross's outlet) predictions of a $0-0.5 \mathrm{~m}$ highstand at 6800 years BP are consistent with existing observations (Thom and Roy, 1985). Predictions for near the Hawkesbury-Macdonald confluence were of a mid-Holocene sea level highstand 1-2 $\mathrm{m}$ above present sea level. In both cases, a gradual fall in sea level to its current position is predicted.

\section{Methods}

Topographic surveying was conducted using a total station and two Trimble 4800 dual phase GPS receivers. All topographic data is tied to mean sea level (Australian Height Datum, AHD). The bedrock profiles of the two valleys 

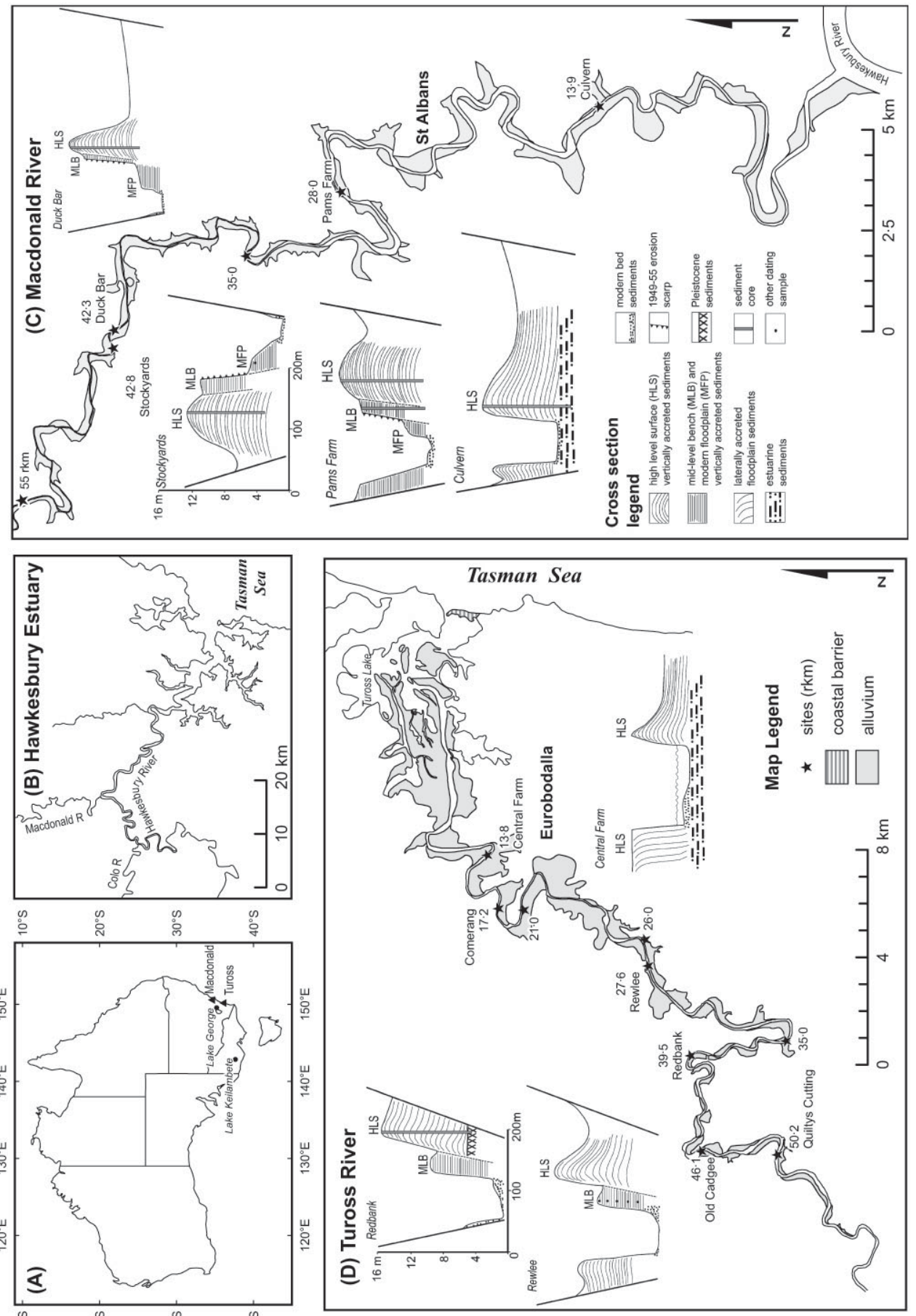

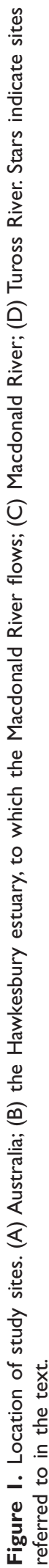




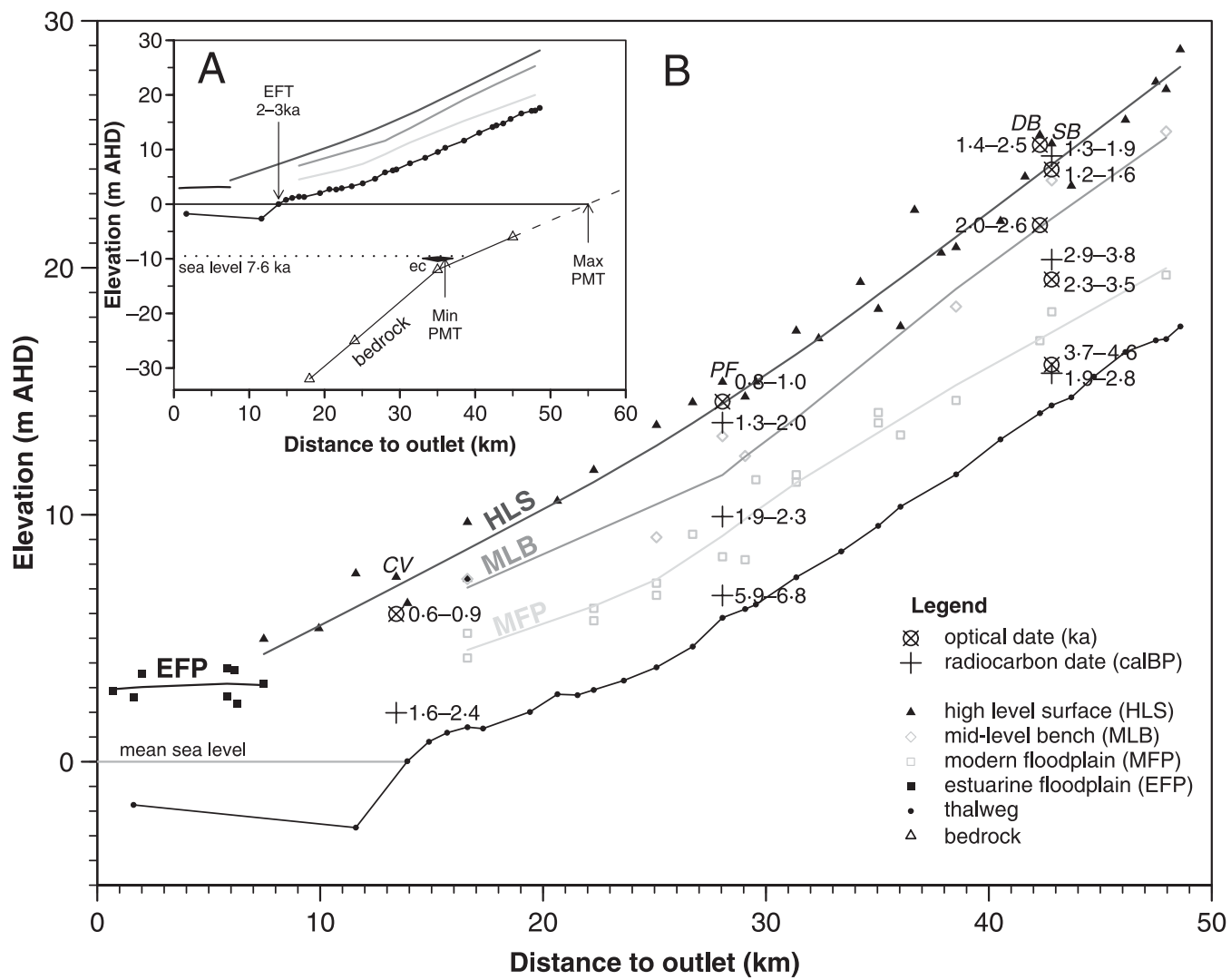

Figure 2. Long profile of the Macdonald River. Inset (A) shows the bedrock profile of the valley and the estuarine clay (ec) referred to in the text along with position of the maximum and minimum post-glacial marine transgressions (Max PMT and Min PMT respectively) and the estuarine to fluvial transition (EFT 2-3 ka) recorded in the Culvern core. The main figure (B) shows an expanded view of the contemporary long profile of the thalweg and the three alluvial surfaces described in the text, along with the dating results, rounded to the nearest $0 \cdot 1$ ka. Sites are labelled as SB, Stockyard Bar; DB, Duck Bar; PF, Pams Farm; CV, Culvern.

were reconstructed from bedrock intercepts noted in groundwater bore logs and from field exposures. Alluvial stratigraphy was examined through excavated pits, by hand augering and using $50 \mathrm{~mm}$ diameter sediment cores collected using a truck mounted drill rig. Sediment cores were collected from the Macdonald River at sites referred to as Stockyard Bar, Pams Farm and Culvern, located at 42.8, 28.0 and $13.9 \mathrm{rkm}$ respectively (Figures 1 and 2), complemented by optical dating samples from a soil pit at Duck Bar $(42.3 \mathrm{rkm})$. A sediment core was collected from the Tuross River at Redbank $(39.5 \mathrm{rkm})$ and optical and radiocarbon dates from this core are complemented by those obtained from excavations at a number of other sites, shown in Figures 1 and 3.

The sediment cores were divided into depositional layers using the former ground surfaces and sediment texture as stratigraphic markers. Sand grains $180-212 \mu \mathrm{m}$ in diameter were prepared for optical dating using standard purification procedures described by Olley et al. (2004). Burial doses $\left(D_{\mathrm{b}}\right)$ were estimated using the minimum age model for samples with an over-dispersion coefficient greater than 20 per cent and the central age model for all others (Galbraith et al., 1999; Olley et al., 2004). High resolution gamma spectroscopy was used to estimate the dose rate from radionuclides in the surrounding soil (Olley et al., 2004). In order to align the optical dates with the radiocarbon chronology, optical ages are expressed in years before AD $1950 \pm$ one standard error, where AD 1950 is radiocarbon year zero (Stuiver and Polach, 1977). Table I lists the optical dating results for this study.

Detrital charcoal fragments ( $>1 \mathrm{~mm}$ diameter) were collected for radiocarbon dating by wet-sieving the sediment and pre-treated using an acid-base-acid pre-treatment (Olsson, 1979). All radiocarbon dates are expressed as calibrated age ranges at the 95 per cent confidence level using the two-sigma error value of the radiocarbon date and are denoted calBP (i.e. calibrated years before present $=\mathrm{AD}$ 1950). Oxcal version $3 \cdot 8$ (Bronk-Ramsey, 2001), using atmospheric ${ }^{14} \mathrm{C}$ data contained in the work of Stuiver et al. (1998), was used to calibrate the radiocarbon dates. 


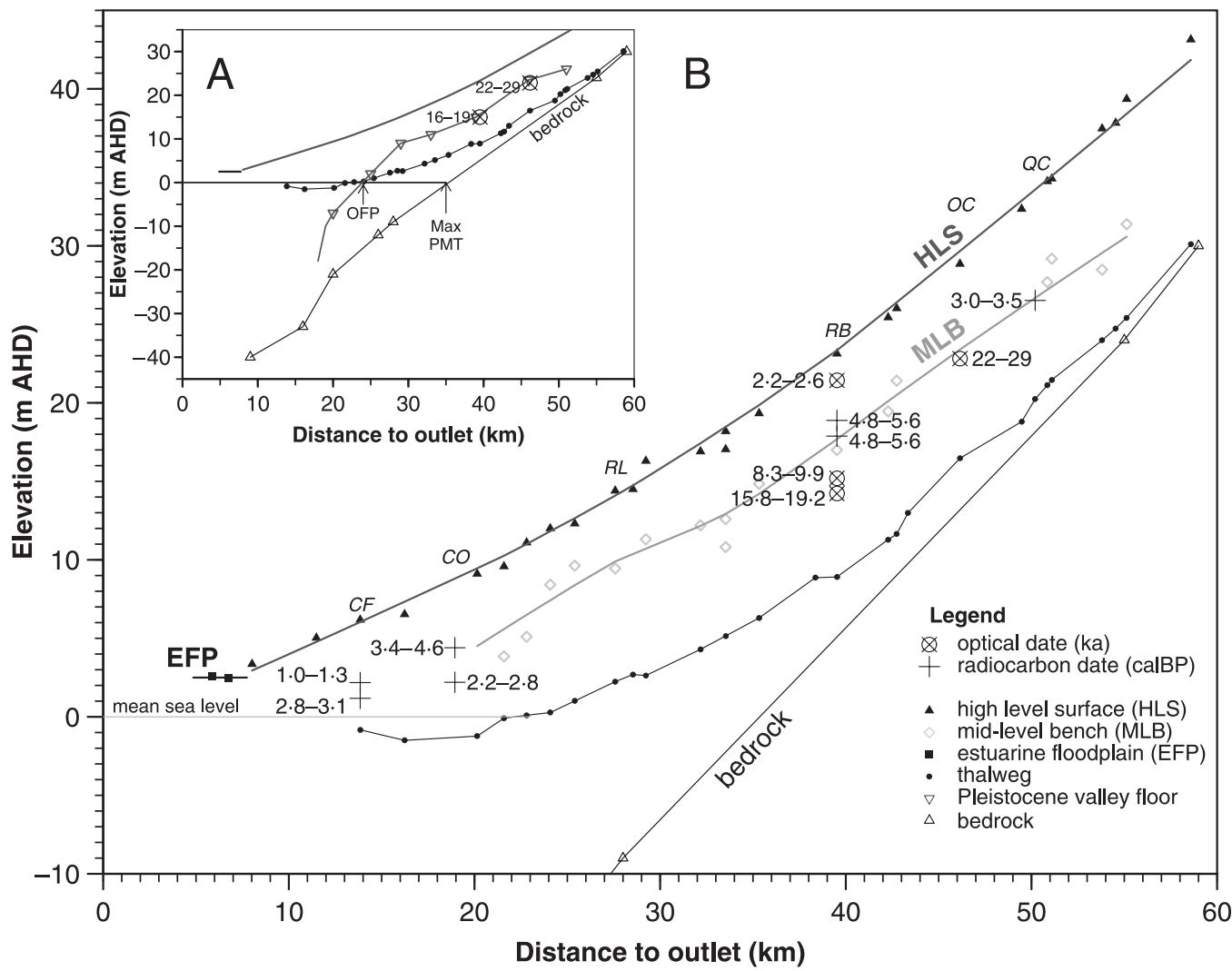

Figure 3. Long profile of the Tuross River. Inset (A) shows the bedrock profile of the valley, with position of the maximum postglacial marine transgressions (Max PMT), the origin of floodplain progradation (OFP), the Pleistocene valley floor, the high level surface and estuarine floodplain. The main figure (B) shows an expanded view of the contemporary long profile, the two alluvial surfaces along the river and the dating results from the Pleistocene and high level surface alluvium, rounded to the nearest $0 \cdot 1 \mathrm{ka}$. Sites are labelled as QC, Quiltys Cutting; OC, Old Cadgee; RB, Redbank; RL, Rewlee; CO, Comerang; CF, Central Farm.

Table I. Optical dating results. $D_{r}$ is dose rate for the sample (radiogenic and cosmic sources); $\sigma$ is dose over-dispersion parameter (see Olley et al., 2004); $D_{\mathrm{b}}$ is burial dose. Year zero is taken as AD 1950 to align the optical and radiocarbon dating results.

\begin{tabular}{|c|c|c|c|c|c|c|c|}
\hline Sample & Site & $\begin{array}{l}\text { Depth } \\
(\mathrm{m})\end{array}$ & $\begin{array}{l}\text { Water } \\
(\% \text { ww) }\end{array}$ & $\begin{array}{c}D_{r} \\
\left(m G y y r^{-1}\right)\end{array}$ & $\begin{array}{c}\sigma \\
(\%)\end{array}$ & $\begin{array}{l}D_{b} \\
(G y)\end{array}$ & $\begin{array}{l}\text { Age } \\
(y r)\end{array}$ \\
\hline \multicolumn{8}{|l|}{ Macdonald River } \\
\hline MDDB-A & Duck Bar HLS & 0.4 & $3 \cdot 2$ & $0.76 \pm 0.05$ & 43 & $1 \cdot 5 \pm 0.4$ & $1900 \pm 550$ \\
\hline MDDB-B & Duck Bar HLS & $3 \cdot 65$ & $15 \cdot 7$ & $1 \cdot 75 \pm 0.14$ & 34 & $4 \cdot 0 \pm 0 \cdot 4$ & $2250 \pm 300$ \\
\hline MRSB-E & Stockyards FP & $0 \cdot 45$ & $|\cdot|$ & $0.85 \pm 0.07$ & 124 & $0.09 \pm 0.06$ & $45 \pm 70$ \\
\hline MRSB-F & Stockyards HLS & $1 \cdot 05$ & $6 \cdot 3$ & $1 \cdot 65 \pm 0 \cdot 14$ & 45 & $2 \cdot 30 \pm 0.25$ & $1350 \pm 200$ \\
\hline MRSB-C & Stockyards HLS & $5 \cdot 5$ & $2 \cdot 1$ & $1.46 \pm 0.13$ & 24 & $4 \cdot 3 \pm 0 \cdot 8$ & $2900 \pm 600$ \\
\hline MRSB-G & Stockyards HLS & 8.94 & $13 \cdot 6$ & $1 \cdot 26 \pm 0 \cdot 11$ & 23 & $5 \cdot 3 \pm 0 \cdot 3$ & $4170 \pm 460$ \\
\hline MRPF-BCA & Pams Farm HLS & $0 \cdot 8$ & 4 & $1.58 \pm 0.13$ & 74 & $1.49 \pm 0.14$ & $895 \pm 120$ \\
\hline MRPFMB-B2 & Pams Farm MLB & $0 \cdot 75$ & $2 \cdot 8$ & $1 \cdot 19 \pm 0 \cdot 1$ & 62 & $0.83 \pm 0.10$ & $650 \pm 100$ \\
\hline MRPFMB-BIO & Pams Farm MLB & $4 \cdot 8$ & 1 & $0.72 \pm 0.07$ & 52 & $0.9 \pm 0.13$ & $1200 \pm 125$ \\
\hline MRCV-B4 & Culvern HLS & $1 \cdot 5$ & 8 & $1 \cdot 72 \pm 0 \cdot 14$ & 46 & $1 \cdot 41 \pm 0.20$ & $770 \pm 140$ \\
\hline \multicolumn{8}{|l|}{ Tuross River } \\
\hline TRRB-BARR5 & Redbank HLS & $1 \cdot 7$ & $7 \cdot 4$ & $5 \cdot 4 \pm 0 \cdot 4$ & 17 & $13 \cdot 1 \pm 0 \cdot 4$ & $2390 \pm 220$ \\
\hline TRRB-BARR I 8 & Redbank HLS & $8 \cdot 1$ & $18 \cdot 4$ & $4 \cdot 3 \pm 0 \cdot 3$ & 7 & $39 \cdot 7 \pm 0 \cdot 8$ & $9100 \pm 800$ \\
\hline TRRB-BARR 19 & Redbank HLS & $8 \cdot 45$ & 16.5 & $3 \cdot 0 \pm 0 \cdot 3$ & 18 & $52 \cdot 4 \pm 1 \cdot 2$ & $17450 \pm 1700$ \\
\hline TROC-REDI & Old Cadgee & $3 \cdot 0$ & $10 \cdot 2$ & $5 \cdot 3 \pm 0 \cdot 4$ & 14 & $139 \pm 14$ & $25950 \pm 3500$ \\
\hline
\end{tabular}


Table II. Radiocarbon dating results for the Macdonald and Tuross rivers. Note HLS $=$ high level surface and MLB $=$ mid-level bench. The Riverview dates are shown in line with Central Farm in Figure 3. The Comerang and Riverview dates are from laterally accreted floodplains and are reproduced with permission from John Wiley and Sons Limited.

\begin{tabular}{|c|c|c|c|c|c|}
\hline Lab. code & Site & Sample & Depth (m) & Radiocarbon age (yr) & Calibrated age range $(y r)$ \\
\hline \multicolumn{6}{|c|}{ Macdonald River } \\
\hline ANU-12008 & Stockyards HLS & MRSB-B2 & 0.63 & $1660 \pm 140$ & $1300-1900$ \\
\hline ANU- 12012 & Stockyards HLS & MRSB-B9 & $4 \cdot 69$ & $3150 \pm 150$ & $2900-3750$ \\
\hline ANU-12011 & Stockyards HLS & MRSB-B|8 & $9 \cdot 27$ & $2260 \pm 130$ & $1900-2750$ \\
\hline ANU- 12010 & Pams Farm HLS & MRPFBC-B3 & 1.65 & $1680 \pm 150$ & $1250-1950$ \\
\hline ANU-12007 & Pams Farm HLS & MRPFBC-B|4 & $8 \cdot 65$ & $5560 \pm 170$ & $5900-6750$ \\
\hline ANU- 12047 & Pams Farm HLS & MRPFBC-545 & $5 \cdot 45$ & $2100 \pm 70$ & $1890-2310$ \\
\hline ANU-12009 & Pams Farm MLB & MRPMB-BI2 & $5 \cdot 65$ & $1320 \pm 80$ & $1050-1390$ \\
\hline ANU-12046 & Culvern HLS & MRCV-550 & $5 \cdot 50$ & $2020 \pm 150$ & $1600-2350$ \\
\hline \multicolumn{6}{|l|}{ Tuross River } \\
\hline ANU-1 1968 & Redbank HLS & TRRB-BIO & $4 \cdot 07$ & $4560 \pm 160$ & $4800-5600$ \\
\hline ANU-1 1967 & Redbank HLS & TRRB-B 12 & $5 \cdot 23$ & $4550 \pm 160$ & $4800-5600$ \\
\hline ANU-1 1969 & Quiltys HLS & TRQC-I & $3 \cdot 0-5 \cdot 0$ & $3060 \pm 90$ & $2990-3470$ \\
\hline ANU-I 1974 & Rewlee MLB & TRRL-B5 & $0 \cdot 15$ & $410 \pm 60$ & $310-540$ \\
\hline ANU-1 197| & Rewlee MLB & TRRB-BI & $0 \cdot 35$ & $730 \pm 60$ & $560-760$ \\
\hline ANU-1 1973 & Rewlee MLB & TRRB-B4 & $0 \cdot 80$ & $550 \pm 60$ & $510-650$ \\
\hline ANU-I 1970 & Rewlee MLB & TRRB-B2 & $1 \cdot 20$ & $600 \pm 60$ & $520-670$ \\
\hline ANU-1 1972 & Rewlee MLB & TRRB-B3 & 3.00 & $1100 \pm 60$ & $930-1170$ \\
\hline \multicolumn{6}{|c|}{ Tuross River from Ferguson and Brierley (1999b) \& Ferguson (1999) } \\
\hline OZC304 & Comerang & $195 \mathrm{~m}$ from bank top & $4 \cdot 7$ & $3610 \pm 220$ & $3350-4550$ \\
\hline OZC305 & Comerang & $50 \mathrm{~m}$ from bank top & 6.9 & $2320 \pm 50$ & $2150-2750$ \\
\hline OZB918 & Riverview & $281 \mathrm{~m}$ from bank top & $4 \cdot 5$ & $2780 \pm 70$ & $2750-3080$ \\
\hline OZB917 & Riverview & $41 \mathrm{~m}$ from bank top & $4 \cdot 3$ & $1190 \pm 70$ & $960-1270$ \\
\hline Not given & Rewlee MLB & & 4 & $1640 \pm 50$ & $1410-1700$ \\
\hline
\end{tabular}

Table II lists the radiocarbon dating results for this study. Note that reference to the mid-Holocene sea level highstand given by Lambeck and Nakada (1990) is in calibrated years BP.

\section{Results}

\section{Progradation history of the Macdonald River}

If the bedrock profile of the Macdonald River (Figure 2(A)) is extrapolated upstream, it intersects $2 \mathrm{~m}$ AHD at approximately $55 \mathrm{rkm}$. This point, labelled as 'Max PMT' in Figure 2(A), represents the maximum upstream limit for the post-glacial marine transgression at the time of the mid-Holocene sea level highstand. Estuarine clay, noted at $-10 \mathrm{~m}$ AHD in a groundwater bore log at $35 \mathrm{rkm}$, indicates that the post-glacial marine transgression extended at least this far inland. This point of minimum post-glacial marine transgression is labelled as 'Min PMT' in Figure 2(A). Based on its elevation, this estuarine clay must post-date 7600 years BP (Thom and Roy, 1985).

The chronology and stratigraphy of the Culvern core (shown in Figure 4) collected from $13.9 \mathrm{rkm}$ are used to define the progradation of the Macdonald River since the mid-Holocene sea level highstand (at which time we assume the fluvio-deltaic front was close to MaxPMT in Figure 2(A)). This $950 \mathrm{~cm}$ long core was extracted from the crest of an alluvial bar comprising fluvial sediments to a depth of $720 \mathrm{~cm}$, a non-recovered section from 720 to $790 \mathrm{~cm}$ (and spanning $0 \mathrm{~m} \mathrm{AHD)}$ and estuarine clay and sand below this. This sequence results from the prograding river mouth of the Macdonald River passing this point in the valley. Extrapolation of the age-depth relationship from the fluvial sediments (see below) to the top of the estuarine sediments suggests that the estuarine to fluvial transition occurred at Culvern between 2000 and 3000 years BP. This point is labelled as EFT in Figure 2.

Using these observations, we constrain the Macdonald River's progradation history to three scenarios. A minimum progradation rate for the reach above Culvern assumes progradation of the fluvio-deltaic front from the estuarine clay layer at $35 \mathrm{rkm}$ to Culvern (13.9 rkm) over the interval 7600 to $2000-3000$ years BP at $4.3 \pm 0.4 \mathrm{~m} \mathrm{a}^{-1}$. A maximum 


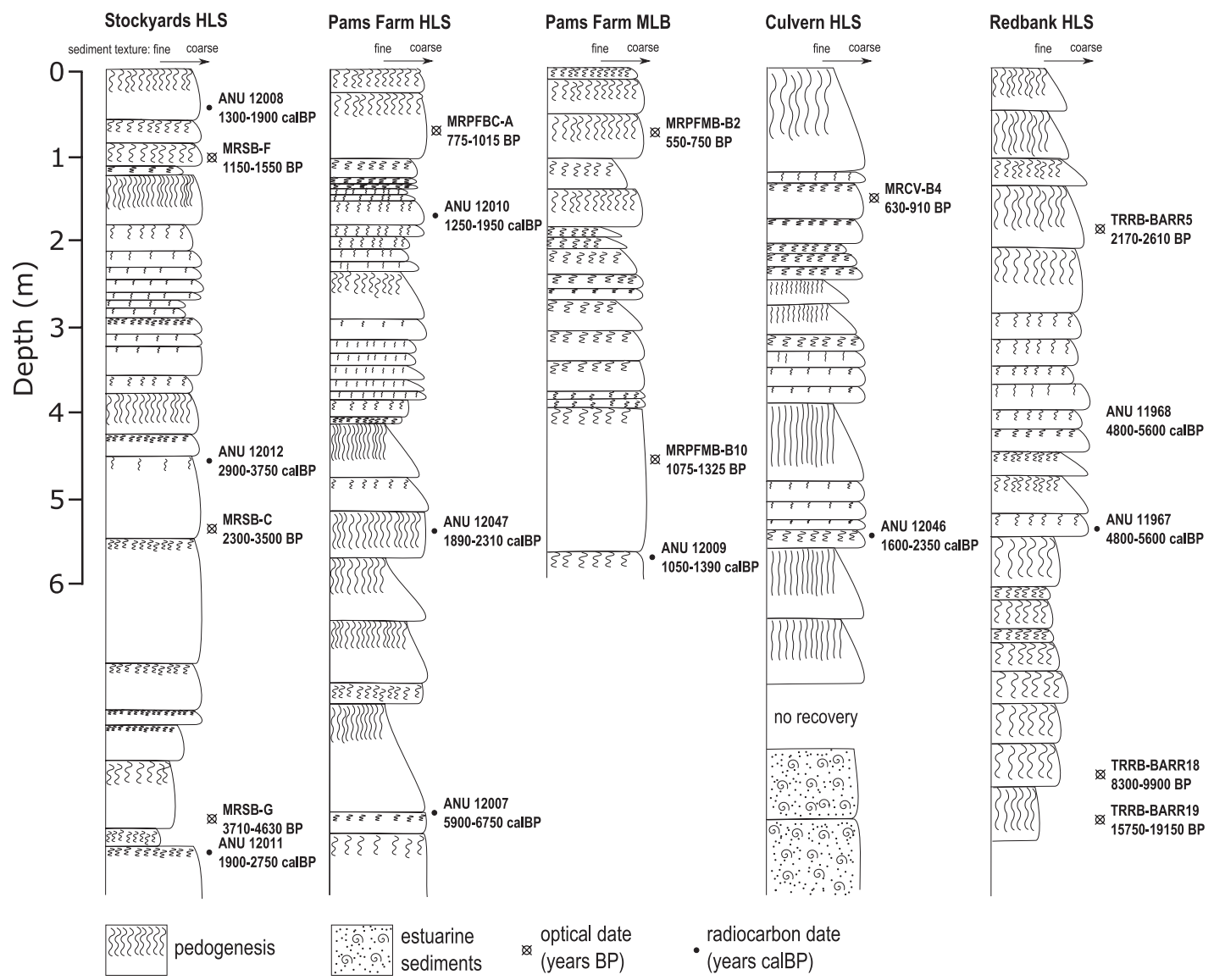

Figure 4. Stratigraphic profiles of sediment cores. HLS denotes the high level surface of each river, whilst MLB denotes the profile is from a mid-level bench. The sediment texture measure is an integrated representation of the proportion of silt and clay relative to the proportion of sand and the particle size of the sand grains.

progradation rate for the same reach uses the maximum post-glacial marine transgression, with marine water potentially having reached $55 \mathrm{rkm}$ at 6800 years BP, with progradation then extending to Culvern as for the minimum model at $9.9 \pm 1.2 \mathrm{~m} \mathrm{a}^{-1}$. These values represent extremes in the range of progradation rates for this time period and some intermediate rate may have prevailed.

The Macdonald River has prograded to its confluence with the Hawkesbury River and, while it is unknown when after the 2000-3000 year BP estuarine to fluvial transition at Culvern it achieved this, the floodplains below Culvern are well established. A minimum progradation rate for the reach downstream of Culvern is obtained by assuming the fluvio-deltaic front has just reached the Hawkesbury River and dividing the $13.9 \mathrm{rkm}$ between Culvern and the Hawkesbury River by the 2000-3000 years estimated to have elapsed since the estuarine to fluvial transition at Culvern. A minimum progradation rate of $5.9 \pm 1.2 \mathrm{~m} \mathrm{a}^{-1}$ results for this lower reach, which is within the range of values defined upstream. The expected aggradation rates that these progradation models are likely to have produced if our model applies, given the assumption that the present alluvial bed gradient of 0.0006 represents an equilibrium bed gradient, range from 2.3 to $6.7 \mathrm{~mm} \mathrm{a}^{-1}$. Distinct epochs are associated with each of the three predicted aggradation rates and these are shown in Figure 5 as shaded boxes.

\section{Progradation history of the Tuross River}

The bedrock profile of the Tuross River crosses $0 \mathrm{~m}$ AHD at approximately $35 \mathrm{rkm}$ (Figure 3(A)), and this represents the maximum post-glacial marine transgression of the valley at the time of the mid-Holocene sea level highstand. Subsequent progradation of this river can be measured in two ways. First, the downstream change in the position of 


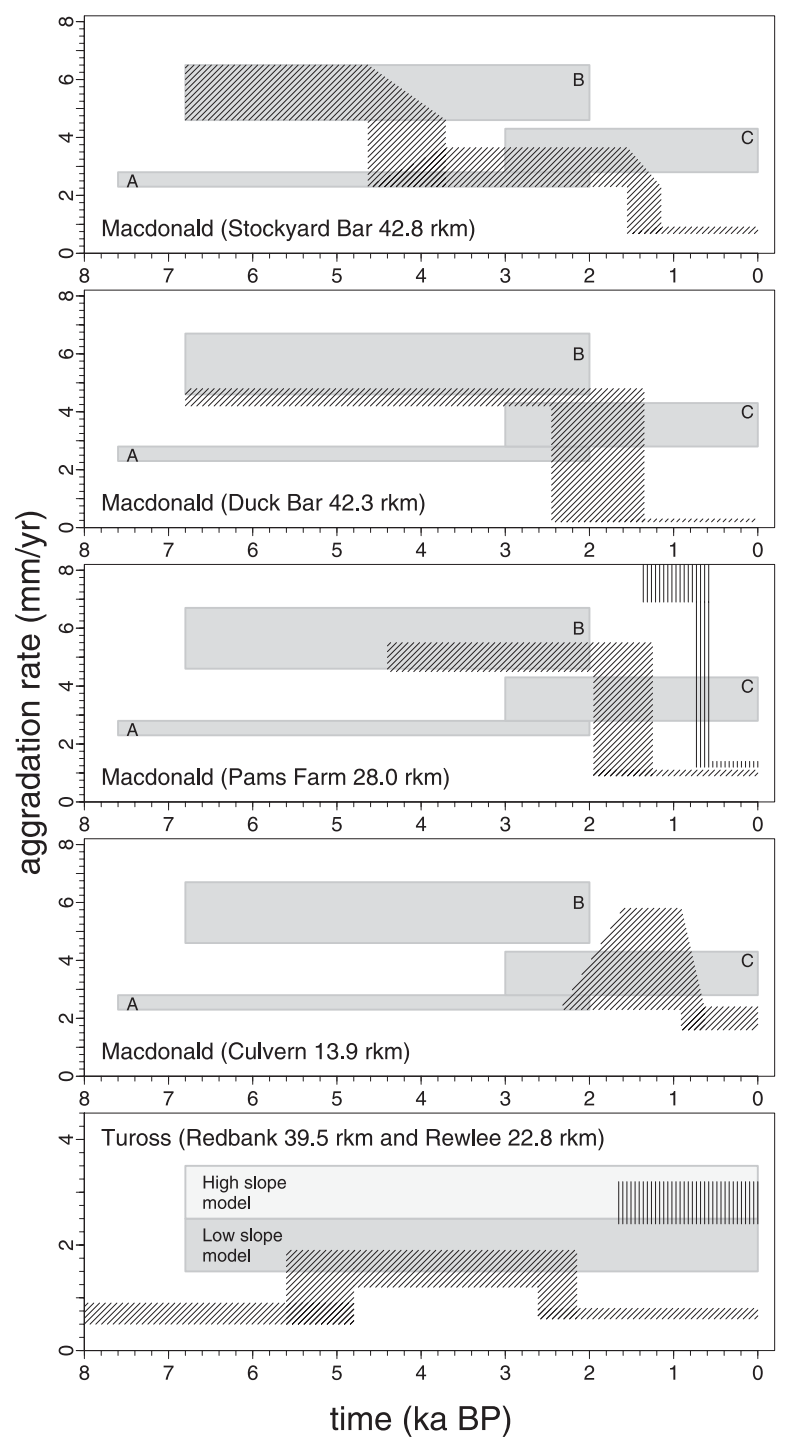

Figure 5. Observed and predicted floodplain aggradation rates for the Macdonald and Tuross Rivers. The grey shaded boxes indicate for the Macdonald River the predicted aggradation rates for (A) the maximum and $(B)$ minimum progradation models for reach above Culvern and $(C)$ the minimum progradation model for the reach below Culvern. For the Tuross, the two shaded boxes correspond to the predictions from the high and low bed gradients and the two progradation models. The black diagonal hatching shows the observed vertical aggradation rates for the high level surface and the vertical hatching shows the vertical aggradation rate of the mid-level bench. Note that for the Macdonald aggradation rates between $(A)$ and (B) are acceptable.

the river mouth, currently represented by the delta tip extending into the estuarine lake (Figure 1(D)), can be used if the position of an equivalent landform can be ascertained at the time of the mid-Holocene sea level highstand. Secondly, the change in position of the thalweg's intersection with $0 \mathrm{~m}$ AHD can be used.

Using the first method, it is necessary to account for the presence of Pleistocene alluvium, typically indurated, clay rich and orange in colour, within the Tuross valley at elevations averaging $12 \mathrm{~m}$ above the bedrock profile. On the basis of textural and color descriptions and optical dating of sediments discussed below, these are inferred to be Pleistocene sediments preserved in the valley since at least the last sea level lowstand. The top of this alluvium is shown as 'Pleistocene valley floor' in Figure 3(A). If, during the last sea level lowstand, the channel had incised through this Pleistocene alluvium to bedrock and the post-glacial marine transgression penetrated to $35 \mathrm{rkm}$ at 6800 years BP, the point at which extensive floodplain formation would have occurred would have been displaced downstream 
to approximately $26 \mathrm{rkm}$ by this Pleistocene alluvium, as this is where this palaeo-surface dips below $0 \mathrm{~m}$ AHD. This point is referred to as the origin of floodplain formation (OFP) in Figure 3(A). Given that the river mouth is situated $3 \mathrm{~km}$ inland of the coastal barrier, this implies $23 \mathrm{rkm}$ of fluvio-deltaic progradation has occurred at a rate of $3.4 \mathrm{~m} \mathrm{a}^{-1}$ since the mid-Holocene sea level highstand. If the second measure of progradation is adopted, a maximum downstream shift in the thalweg's intersection with $0 \mathrm{~m} \mathrm{AHD}$ at $35 \mathrm{rkm}$ to its present intersection at $21 \mathrm{rkm}$ (Figure 3B) occurred in 6800 years, yielding a maximum progradation rate of $2 \cdot 1 \mathrm{~m} \mathrm{a}^{-1}$.

In contrast to the Macdonald River's essentially straight profile, the Tuross River has a concave upwards profile with a steeper cobble bed reach grading to a flatter sand bed reach. The sand and cobble bed reaches have bed gradients of 0.0007 and 0.0011 respectively and we use these two values to predict the aggradation rates expected for the valley. The lower bed gradient results in an aggradation rate prediction of $2.0 \pm 0.5 \mathrm{~mm} \mathrm{a}^{-1}$ for the two progradation models, while the steeper bed gradient results in an aggradation rate prediction of $3.0 \pm 0.5 \mathrm{~mm} \mathrm{a}^{-1}$. Figure 5 shows the predicted aggradation rates for the Tuross associated with the two progradation models.

\section{Alluvial aggradation of the Macdonald River}

The Macdonald River has formed a range of fluvial landforms including alluvial bars, levees, benches and flood basins through flood flows interacting with the narrow and tightly curved bedrock trough. Topographic relief from the thalweg to the highest bar crests exceeds $10 \mathrm{~m}$ and the morphology of these bars suggests that they were formed during floods in flow separation zones such as those described by Ferguson et al. (2003). The bars and levees along the Macdonald River are referred to collectively as the 'high level surface' and can be traced from the head of the study reach to within $7 \mathrm{rkm}$ of the Hawkesbury River. Inset below the high level surface is a mid-level bench. A low relief estuarine floodplain occurs along the lower $7 \mathrm{rkm}$. Cross sections showing the floodplain topography and relationship of the main floodplain elements are shown in Figure 1(C).

Vertical aggradation rates of the high level surface and mid-level bench have been calculated using linear agedepth regressions for sections of core bracketed by direct dating observations (using the mean of the optical and radiocarbon date ranges) with the exceptions noted below. These regressions were accepted if they intersected the observed ages given their uncertainties. Aggradation rate uncertainties correspond to the standard error of the regression coefficients or, when only two date points are used, the aggradation uncertainty is based on the dating uncertainties.

For the Stockyards, Duck Bar and Pams Farm sites on the Macdonald River, the aggradation rate of the sediment beneath the lowest direct date has been obtained by estimating the timing and elevation of the river mouth passing these points in the valley. This was at approximately $2 \mathrm{~m}$ AHD at 6800 years BP for the Stockyards and Duck Bar sites (based on the maximum progradation model above Culvern). At Pams Farm, passage of the fluvio-deltaic front is estimated to have occurred at approximately $1 \mathrm{~m}$ AHD at $5950 \pm 150$ years BP (for the minimum progradation model above Culvern) and approximately $1 \mathrm{~m}$ AHD at $4050 \pm 350$ years BP (for the maximum progradation model above Culvern). Aggradation rates for sediments above the uppermost dated layer are calculated by assuming that the present ground surface has zero age. These are minimum apparent aggradation rates, as aggradation may in fact have ceased at some time in the past.

Radiocarbon dates from the Macdonald River floodplain sediments presented a less consistent chronology than the optical dates in a number of cases and, in these cases, the inconsistent radiocarbon dates have been removed from the aggradation calculations. These include the three radiocarbon dates from the Stockyards core, the top two of which were in stratigraphically correct order but 500-1000 years older than the optical dates. The lowest radiocarbon date from the Stockyards is younger than the optical date immediately above it and the next highest radiocarbon date. The intact depositional stratigraphy of the core indicates that bioturbation did not transport large, young charcoal fragments to depth; however, contamination of this lowermost radiocarbon sample with younger, illuviated particulate carbon possibly accounts for its young age. The age offset between the top two radiocarbon dates and the optical dates may reflect a pre-existing radiocarbon age of the charcoal fragments prior to burial, as described by Blong and Gillespie (1978). In this case, the three optical dates are taken to more accurately reflect the burial age of the sediment and are used to estimate the aggradation rate.

At Pams Farm, the lowermost radiocarbon date from the core (ANU-12007, 5900-6750 calBP) gives inconsistent aggradation results. It implies an unusually low aggradation rate for the sediments immediately above it and more significantly is also inconsistent with the progradation history of the river. If the minimum progradation model for the upper reach applied, the fluvio-deltaic front is estimated have passed Pams Farm at 5800-6100 years BP. This implies that aggradation was occurring near sea level (approximately at $1 \mathrm{~m} \mathrm{AHD)}$ ) at this time, rather than at the $6 \mathrm{~m}$ AHD position of sample ANU-12007. A substantial age inversion is obtained if the maximum progradation model upper reach is applied, with the fluvio-deltaic front predicted to have passed Pams Farm at 4100-4400 years BP, thus 
making it impossible to accumulate older sediments at an elevation of $+6 \mathrm{~m}$ AHD. Sample ANU-12007 most likely had a substantial pre-existing radiocarbon age when buried, and its age is unlikely to reflect the depositional age of the sediment.

At the Stockyards site, the vertical aggradation rates concur with the predicted rates up until 1500 years BP (Figure 5), indicating aggradation was consistent with the progradation based model except for this latter period. A consistent decline in floodplain aggradation rate after the mid-Holocene sea level highstand is also evident. At Duck Bar, $500 \mathrm{~m}$ downstream of the Stockyards, the measured aggradation rates again coincide with the predictions up until approximately 2000 years BP, when they decline substantially below the predicted rates. At Pams Farm, the simplest agedepth interpretation involves sediment accumulating between $1 \mathrm{~m} \mathrm{AHD} \mathrm{(at} 4050 \pm 350$ years BP according to the maximum progradation model) and $13.7 \mathrm{~m}$ AHD (the uppermost radiocarbon date, ANU-12010) at 5.0 $\pm 0.5 \mathrm{~mm} \mathrm{a}$, with subsequent aggradation of sediment above ANU-12010 at a slower rate $1 \cdot 0 \pm 0 \cdot 1 \mathrm{~mm} \mathrm{a}^{-1}$. Again, apart from the last 1500 years, vertical aggradation of sediment was consistent with the predicted rate. If the fluvio-deltaic front is assumed to have passed Pams Farm according to the minimum progradation model, a less parsimonious aggradation history is required. At Culvern, aggradation of the $4 \mathrm{~m}$ of fluvial sediments bracketed by the two dates aggraded at $4.1 \pm 1.8 \mathrm{~mm} \mathrm{a}^{-1}$, consistent with the predictions until approximately 1000 years BP, when aggradation of the high level surface declined at this site.

Aggradation of the alluvial bench below the high level surface of the Macdonald River is measured from a $600 \mathrm{~cm}$ core from Pams Farm. Bench aggradation occurred from 1050-1390 calBP until at least 550-750 calBP at $8 \cdot 0 \pm 1 \cdot 1 \mathrm{~mm} \mathrm{a}^{-1}$, with aggradation of the uppermost $75 \mathrm{~cm}$ of sediment occurring at a lower rate of $1 \cdot 2 \pm 0 \cdot 2 \mathrm{~mm} \mathrm{a}$. The present day ground surface sediments show the most extensive pedogenesis, consistent with their lower aggradation rate. Bench aggradation most likely followed abandonment of the high level surface as an actively accreting floodplain at Pams Farm. However, bench aggradation effectively ceased after 550-750 years BP. The AD 1949-1955 floods incised laterally into the mid-level bench along the river, forming an erosion scarp below which the Macdonald's contemporary floodplain is accreting (Figure 1(C)). Optical date MRSB-E from $45 \mathrm{~cm}$ depth (below an incipient soil horizon) from this floodplain at the Stockyards was dated to AD 1825-1965, consistent with sediment deposition after the AD 1949-1955 floods.

\section{Alluvial aggradation of the Tuross River}

The alluvial landscape of the Tuross River contains a number of distinct alluvial surfaces, the highest and most extensive of which is typically 10-14 $\mathrm{m}$ above and generally parallel to the thalweg except as each converges with mean sea level in the estuary (Figure 3). The laterally accreted floodplains described by Ferguson and Brierley (1999b) form part of this high level surface, which then grades into an estuarine floodplain comprising a birdsfoot delta protruding into Tuross Lake (Figure 1). In some locations this high level surface extends as a plain gently dipping from the channel to distal backswamps and floodbasins. In more tightly curved valley settings, it exists as a longitudinally aligned flow separation bar or narrow floodplain pocket along the river's inner bank. A secondary alluvial surface, referred to here as the mid-level bench, has also been recognized along the valley (Ferguson and Brierley, 1999a, 1999b), and is inset within the alluvium of the high level surface, rises 6-8 $\mathrm{m}$ above the thalweg and is usually less than $50 \mathrm{~m}$ wide (Figure 1(D)).

The Redbank high level surface core consists mainly of vertically accreted sands. Indurated clay-rich, fine to coarse sandy sediments, light orange in colour and containing angular stone chips, comprise the lowermost $50 \mathrm{~cm}$ of the core. The orange colour, induration and high clay content differentiate these sediments from those overlying them, and an optical date of 15.8-19.2 ka (Figure 4) indicates a Pleistocene depositional age.

Above these Pleistocene sediments and extending upwards to $540 \mathrm{~cm}$ depth, vertically accreted layers of homogenous fine to very coarse sand, brown to dark-brown in colour, occur. A date of 8300-9900 years BP from the base of this group indicates aggradation from the early Holocene at $0.7 \pm 0.2 \mathrm{~mm} \mathrm{a}^{-1}$. Combined with the distinct sedimentary characteristics, this age suggests a stratigraphic disconformity between these Holocene sediments and the Pleistocene substrate.

Between $540 \mathrm{~cm}$ and $150 \mathrm{~cm}$ depth, the sediments are coarser (the modal particle size increases to medium sand and coarse sand) and pedogenesis is weaker. These features suggest rapid accretion and a closer connection between the floodplain and the channel than was previously the case. Deposition of these sediments occurred between 4800-5600 calBP and 2170-2610 years BP at 1.4-1.7 $\mathrm{mm} \mathrm{a}^{-1}$. The uppermost two depositional layers above $150 \mathrm{~cm}$ have a high proportion of silt and clay (approximately 40 per cent), consistent pedogenesis and an apparent aggradation rate of $0.6-0.7 \mathrm{~mm} \mathrm{a}^{-1}$. The changes in the vertical aggradation rate at Redbank are shown in Figure 5. From the middle Holocene onwards, vertical aggradation of sediment at Redbank was consistent with the predicted rate for the low slope model, though it has declined below the predicted rate over the last 2000 years. 
Other dating samples from the Tuross valley provide further insight into its aggradation history. Indurated orange coloured alluvium beneath sandy, high level surface sediments at $46 \cdot 1 \mathrm{rkm}$ (Old Cadgee) yielded an optical age of 22 450-29 450 years BP (TROC-RED1). Together with the basal sediments from the Redbank core, these two late Pleistocene ages form the basis for the earlier assertion of a residual Pleistocene fill preserved within the Tuross valley. A 2990-3470 calBP age of detrital charcoal from sandy high level surface sediments overlying indurated orange coloured cobbles at $50 \cdot 2 \mathrm{rkm}$ (Quiltys Cutting) confirms that the Holocene aggradational phase extended at least this far inland.

A sand extraction pit in the Tuross River's mid-level bench at Rewlee $(27.6 \mathrm{rkm})$ showed the bench to be constructed from vertically accreted sand drapes interspersed with organic debris and silt. Fine scale stratigraphic detail preserved in the bench sediments and weak pedogenesis suggests both relatively recent and rapid aggradation. Five radiocarbon samples collected from the uppermost $3 \mathrm{~m}$ of bench sediments augment a radiocarbon date published by Ferguson (1999) from charcoal at approximately $4 \mathrm{~m}$ depth with an age of 1410-1700 calBP (Table II). The five bench samples collected for this study are all in stratigraphically correct order and indicate that the uppermost $3 \mathrm{~m}$ of bench aggradation occurred between 930-1170 calBP and 310-540 calBP. Recent flood debris on the bench surface and the general sediment texture suggests that the uppermost date of 310-540 calBP from $15 \mathrm{~cm}$ depth probably reflects a pre-existing radiocarbon age of detrital charcoal prior to burial, and these sediments should be taken as modern. If so, it suggests that the upper $4 \mathrm{~m}$ of bench sediments has aggraded at $2.8 \pm 0.4 \mathrm{~mm} \mathrm{a}^{-1}$. The rate and timing of mid-level bench aggradation is shown in Figure 5.

\section{Discussion}

Figure 5 presents the observed aggradation rates for the Macdonald and Tuross Rivers along with the aggradation rates predicted on the basis of the progradation histories of the two rivers and their present bed gradients. For the Macdonald River, the observed aggradation rates of the high level surface from when post-glacial sea level rise ceased 6800 years ago until approximately 1500 years BP consistently overlap the range of predicted values. This strongly supports our model linking the rate and timing of valley aggradation to progradation of the river mouth, at least for this period. Abandonment of the high level surface of the Macdonald River as an actively accreting floodplain approximately 1000-2000 years ago coincided with aggradation of the mid-level bench, which continued to aggrade, causing the channel to contract until approximately 600 years BP, when it too was abandoned. The AD 1949-55 floods presumably eroded any alluvial landforms formed after mid-level bench abandonment as these floods cut laterally into the mid-level bench. Since these floods, a third lower level floodplain surface has formed. Consequently, the Macdonald River has a stepped sequence of two abandoned floodplain surfaces above and separated from its contemporary, actively aggrading floodplain by a well defined erosion scarp.

Along the Tuross River, there is evidence of moderate floodplain aggradation at Redbank from the early Holocene, though the most rapid aggradational phase occurred between 5500 and 2500 years BP at a rate consistent with that expected from the low slope change in the thalweg progradation model. This is not surprising given that the aggraded sediments consist primarily of sand and the low slope value used to predict the aggradation rate was obtained from the river's sand bed reach. Abandonment of the high level surface of the Tuross River as an actively aggrading floodplain occurred has over the last 2500 years, with subsequent aggradation of the mid-level bench. This change mirrors that observed along the Macdonald River, though continued aggradation of the mid-level bench along the Tuross River contrasts with bench abandonment along the Macdonald River. As is suggested below, this represents a critical difference between the two rivers.

Whilst the general agreement between observed and predicted aggradation rates for the middle Holocene period provides general support for floodplain aggradation being driven by river mouth progradation, there are departures that are of significance. The first is the 1000 year lag between stabilization of post-glacial sea level, the presumed commencement of fluvio-deltaic progradation and the increase in high level surface aggradation rate along the Tuross River at Redbank. The height from bedrock to the top of the Pleistocene surface is approximately $11 \mathrm{~m}$ at Redbank and contemporary floods occasionally exceed this depth. The relatively slow aggradation rate from 9000 until 5600 years BP at Redbank arguably arises from occasional large floods flowing over what was probably still a bedrock thalweg, slowly depositing sediments upon the Pleistocene substrate. Bed aggradation, in response to progradation, would have had to progress upstream and the increase in aggradation rate, particle size and decreased pedogenesis after 5600 years BP suggests that it took about 1000 years for the effects of river mouth progradation, inferred to have proceeded most rapidly after 6800 years BP, to propagate upstream to Redbank.

The second discrepancy between predicted and observed aggradation rates is the decline in aggradation upon the high level surfaces of the two rivers over the last 2500 years. In the case of the Macdonald River, this decline could 
potentially be attributed to the river mouth reaching the Hawkesbury River, thereby ending its capacity for further progradation. While sub-aerial floodplain deposition has reached the Hawkesbury, the thalweg is still $14 \mathrm{rkm}$ from this larger system and arguably has room for additional progradation. The $7 \mathrm{rkm}$ down-valley shift of the thalweg's intersection with mean sea level and $2 \mathrm{~m}$ of bed aggradation in response to the 1949-55 floods is clearly a modern example of the longer term Holocene behaviour of the Macdonald River. It demonstrates that there remains capacity for additional aggradation of the river bed along the valley. The argument of restricted progradation cannot be sustained for the Tuross River either, where ample opportunity exists for continued progradation within its estuary. In any case, declining progradation rates would not account for the formation of the mid-level bench along the two rivers. Given the available chronologies for the two rivers, it appears that abandonment of each river's high level surface, which comprised the main aggradational landform for much of the Holocene, was roughly synchronous, occurring between 2000 and 1000 years BP. High level surface abandonment also appears coincident with initiation of bench aggradation. The coincidence of equivalent changes on two independent river systems is arguably evidence of a regional process as a control.

Abandonment of an actively aggrading alluvial surface indicates a change to the hydraulic conditions of a river. Potentially, this could result from a hydro-climatic change involving a decrease in flood discharges leading to the hydraulic isolation of a former floodplain. A lake level record from Lake Keilambete (location shown in Figure 1(A)) shows low lake levels occurring between 3500 and 2000 years BP (Bowler and Hamada, 1971; Chappell, 1991), mirrored by equivalent changes in Lake George (Coventry and Walker, 1977) and the nearby Breadalbane Basin (Dodson, 1986), both located mid-way between the Macdonald and Tuross Rivers on the Great Dividing Range. This is interpreted to indicate a shift to drier conditions around this time. Unlike at Lake Keilambete where lake levels subsequently rose to a secondary peak, water levels in Lake George and Breadalbane Basin have remained low to the present day indicating relatively dry conditions persisted in the east.

While the lake level records are evidence for reduced regional precipitation, they are less indicative of changes in flood magnitudes, which are driven by rarer, extreme precipitation events. The morphology of the alluvial landforms of the two valleys provides additional evidence to suggest smaller floods have in fact prevailed over the last 2000 years. Along both rivers, the mid-level benches have accreted as channel contraction landforms within the confines of the high level surface alluvium (Figure 1). Channel contraction is a well established response of rivers in south-eastern Australia to periods of smaller floods (Erskine and Bell, 1982; Warner, 1987; Erskine, 1986; Erskine and Warner, 1988). Moreover, along both the Tuross and Macdonald Rivers, the alluvial bars and levees of the high level surface have substantial topographic relief, which we attribute to strong flow separation fields characteristic of large floods occurring in tightly curved valleys. By contrast, the simple on-lapping morphology of the mid-level benches is an indication of construction by smaller, more placid floods. Similar conclusions of quiescent fluvial conditions prevailing over the last several thousand years have been reported elsewhere in south-eastern Australia (Nanson et al., 1995; Kemp, 2001; Nanson et al., 2003). We conclude that, while river mouth progradation was the main factor controlling gross patterns of valley aggradation for much of the Holocene, climate change has also influenced aggradation patterns, particularly over the last 2000 years.

A remaining issue is the abandonment of the mid-level bench along the Macdonald River as an actively aggrading landform over the last 600 years. If a shift to smaller floods has contributed to mid-level bench aggradation along both rivers, how can abandonment of the bench along the Macdonald River and formation of a third floodplain surface below the erosion scarp cut by the 1949-55 floods be accounted for given continued aggradation of the same landform along the Tuross River? Geophysical modelling suggests that the height of the mid-Holocene sea level highstand may have differed between these two systems, with the Macdonald River experiencing a relative base level fall 0.5-2.0 m greater than did the Tuross River (Lambeck and Nakada, 1990). For the Macdonald, the down-stepping sequence of abandoned high level surface, abandoned mid-level bench, erosion scarp and modern floodplain is consistent with the effects of reduced flood magnitudes over the last 2000 years interacting with an isostatically driven base level fall. By contrast, for the Tuross River, where evidence supports at most a $0.5 \mathrm{~m}$ mid-Holocene sea level highstand, the changes in floodplain aggradation patterns are more consistent with a single climatic change.

A schematic model of floodplain aggradation in response to river mouth progradation, drawn from observations of the Macdonald and Tuross Rivers is shown in Figure 6. It starts at 6800 years BP, at the end of the post-glacial sea level rise with the maximum transgression of a bedrock valley by marine water (note that no residual Pleistocene alluvium is shown here). Fluvial sediments delivered from the catchment settle out at the head of the estuary, forming sandy shoals, and this reach has a sediment transport capacity below that required to transport the load delivered from upstream. Aggradation along the prograded reach propagates upstream, causing the thalweg and floodplain to be aggraded. By 2000 years BP, aggradation of the high level surface floodplains in the two study rivers is largely complete, establishing the present day valley floor topography. Subsequently, these mid-Holocene floodplains are abandoned as actively accreting surfaces in response to a shift to smaller floods and in the case of the Macdonald, 


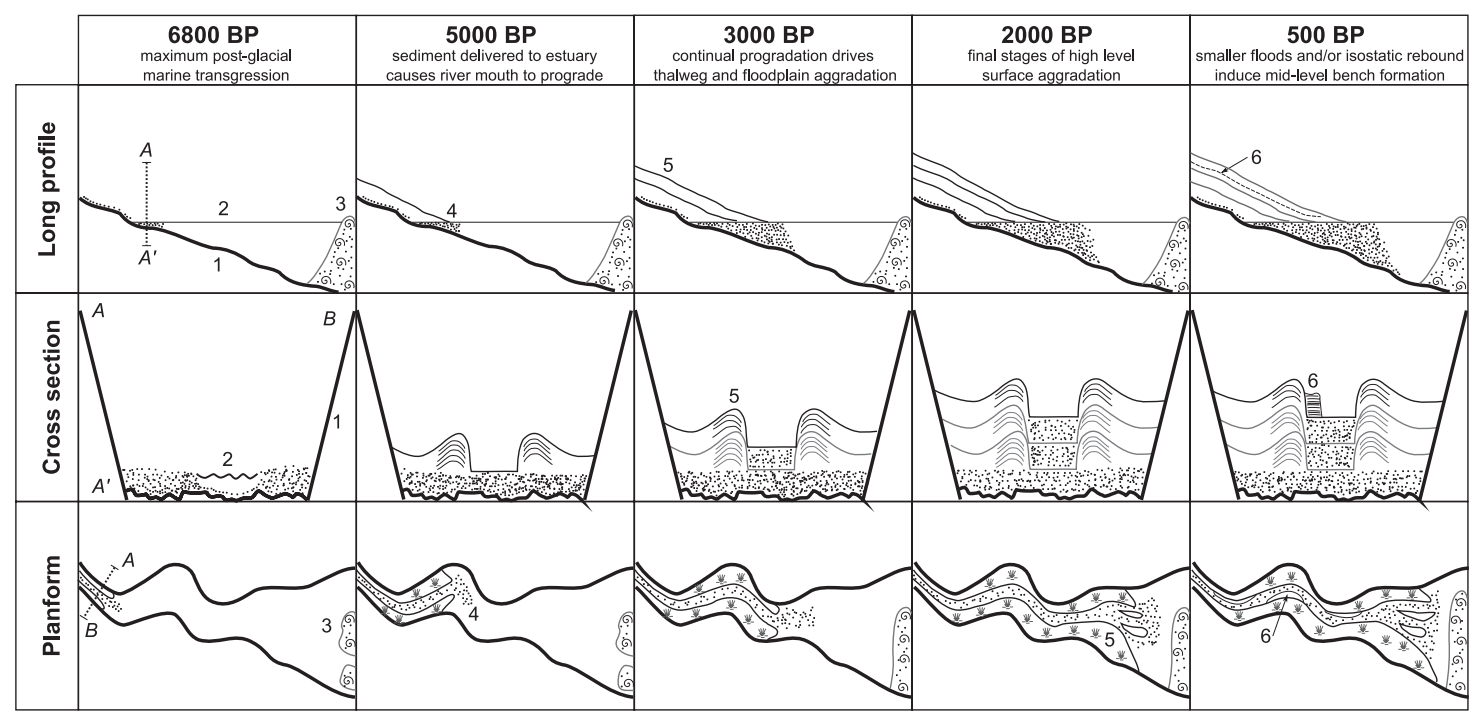

Figure 6. Schematic model of floodplain aggradation driven by fluvio-deltaic progradation applicable to bedrock embayment type estuaries following post-glacial sea level rise. Numbered elements are I, bedrock; 2, sea level; 3, coastal barrier; 4, prograding fluvial sediments; 5 , vertically accreted floodplains; 6, mid-level bench inset below older alluvium.

a relative base level fall caused by hydro-isostatic rebound. Over the last 1500 years, inset benches are formed and the channel contracts.

\section{Conclusions}

A distinct epoch of vertical floodplain aggradation occurred along the lower $50 \mathrm{~km}$ of two narrow coastal valleys in south-eastern Australia once the post-glacial sea level rise ceased 6800 years ago. Both the rate and timing of this aggradation was generally consistent with it being driven by the progradation of each river's mouth into its estuary, indicating progradation drove the alluvial aggradation observed upstream. The abandonment of mid-Holocene floodplains along Macdonald and Tuross Rivers, coupled with channel contraction, is inferred to be a product of smaller floods over the last 2000 years, indicating a secondary influence of climate upon floodplain formation patterns. Different post-glacial hydro-isostatic adjustment between the two catchments appears to account for the subtly different patterns of floodplain evolution of two rivers observed over the last 2000 years. This model for floodplain formation complements existing models of floodplain aggradation proposed for the bedrock valleys of south-eastern Australia, such as the catastrophic floodplain stripping model of Nanson (1986) and the long term climate change model of Nanson et al. (2003) by accounting for the rate and timing of vertical floodplain aggradation over the Holocene where an alluvial connection exists to the prograding river mouth.

\section{Acknowledgements}

Staff at CSIRO Land and Water and the radiocarbon dating laboratory at the Australian National University are thanked for preparation and analysis of dating samples. Many people helped collect the field data and are thanked collectively. Damien Kelleher deserves special thanks for his drilling expertise. PR was supported by an Australian Postgraduate Award and a CSIRO Land and Water postgraduate research scholarship. Gratitude is extended to two reviewers whose comments improved the manuscript.

\section{References}

Blong RJ, Gillespie R. 1978. Fluvially transported charcoal gives erroneous ${ }^{14} \mathrm{C}$ ages for recent deposits. Nature 271: $739-741$.

Bowler JM, Hamada T. 1971. Late Quaternary stratigraphy and radiocarbon chronology of water level fluctuations in Lake Keilambete, Victoria. Nature 232: 330-332. 
Bronk-Ramsey C. 2001. Development of the radiocarbon program oxcal. Radiocarbon 43: 355-363.

Chappell J. 1991. Late Quaternary environmental change in eastern and central Australia and their climatic interpretation. Quaternary Science Reviews 10: 377-390.

Coventry RJ, Walker PH. 1977. Geomorphological significance of late Quaternary deposits of the Lake George area, N.S.W. Australian Geographer 13: 369-376.

Dabrio C, Zazo C, Goy J, Sierro F, Borja F, Lario J, González J, Flores J. 2000. Depositional history of estuarine infill during the last postglacial transgression (Gulf of Cadiz, Southern Spain). Marine Geology 162: 381-404.

Dabrio C, Zazo C, Lario J, Goy JL, Sierro FJ, Borja F, Ángel González J, Flores JA. 1999. Sequence stratigraphy of Holocene incised-valley fills and coastal evolution in the Gulf of Cádiz (southern Spain). Geologie en Mijnbouw 77: 263-281.

Dalrymple RW, Zaitlin BA, Boyd R. 1992. Estuarine facies models: conceptual basis and stratigraphic implications. Journal of Sedimentary Petrology 62: 1130-1146.

Dodson JR. 1986. Holocene vegetation and environments near Goulburn, New South Wales. Australian Journal of Botany 34: $231-249$.

Dodson JR, Thom BG. 1992. Holocene vegetation history from the Hawkesbury Valley, New South Wales. Proceedings of the Linnean Society of New South Wales 113: 122-134.

Erskine WD. 1986. River metamorphosis and environmental change in the Macdonald Valley, New South Wales. Australian Geographical Studies 24: 88-107.

Erskine WD, Bell FC. 1982. Rainfall, flood and river changes in the upper Hunter. Australian Geographical Studies 20: $183-196$.

Erskine WD, Warner RF. 1988. Geomorphic effects of alternating flood and drought dominated regimes on NSW coastal rivers. In Fluvial Geomorphology of Australia, Warner RF (ed.). Academic: Sydney; chapter 11, 223-224.

Ferguson R, Brierley G. 1999a. Levee morphology and sedimentology along the Lower Tuross River, southeastern Australia. Sedimentology 46: 627-648.

Ferguson R, Brierley G. 1999b. Downstream changes in valley confinement as a control on floodplain morphology, lower Tuross River, New South Wales, Australia: a constructivist approach to floodplain analysis. In Varieties of Fluvial Form, Miller AJ, Gupta AJ. (eds). Wiley: New York; 377-407.

Ferguson RI, Parsons DR, Lane SN. 2003. Flow in meander bends with recirculation at the inner bank. Water Resources Research 39: ESG2-1-ESG-2-13.

Ferguson RJ. 1999. Valley Confinement as a Control on Floodplain Evolution on the Lower Tuross River, New South Wales, Australia. PhD Thesis, Department of Physical Geography, Macquarie University.

Galbraith RF, Roberts RG, Laslett GM, Yoshida H, Olley JM. 1999. Optical dating of single and multiple grains of quartz from Jinmium rock shelter, northern Australia. Part I: Experimental design and statistical models. Archaeometry 41: 339-364.

Goodbred SL Jr, Kuehl SA. 2000. The significance of large sediment supply, active tectonism, and eustasy on margin sequence development: Late Quaternary stratigraphy and evolution of the Ganges-Brahmaputra delta. Sedimentary Geology 133: $227-248$.

Henry HM. 1977. Catastrophic channel changes in the Macdonald Valley, New South Wales, 1945-1955. Journal and Proceedings, Royal Society of New South Wales 110: 1-16.

Hori K, Saito Y, Zhao Q, Cheng X, Wang P, Sato Y, Li C. 2001. Sedimentary facies and Holocene progradation of the Changjiang (Yangtze) delta, China. Geomorphology 41: 233-248.

Kayan I. 1999. Holocene stratigraphy and geomorphological evolution of the Aegean coastal plains of Anatolia. Quaternary Science Reviews 18: $541-548$.

Kemp J. 2001. The Hydrology, Geomorphology and Quaternary Palaeochannels of the Lachlan Valley, New South Wales. PhD thesis, Australian National University.

Lambeck K, Nakada M. 1990. Late Pleistocene and Holocene sea-level change along the Australian coast. Palaeogeography, Palaeoclimatology, Palaeoecology 89: 143-176.

Nanson GC. 1986. Episodes of vertical accretion and catastrophic stripping: a model of disequilibrium floodplain development. Geological Society of America Bulletin 97: 1467-1475.

Nanson G, Barbetti M, Taylor G. 1995. River stabilisation due to changing climate and vegetation during the late Quarternary in western Tasmania, Australia. Geomorphology 13: 145-158.

Nanson GC, Cohen TJ, Doyle CJ, Price DM. 2003. Alluvial evidence of major late-Quaternary climate and flow-regime changes on the coastal rivers of New South Wales, Australia. In Palaeohydrology: Understanding Global Change, Gregory KJ, Benito G. (eds). Wiley: New York; 233-258.

Nichol SL, Zaitlin BA, Thom BG. 1997. The upper Hawkesbury River, New South Wales, Australia: a Holocene example of an estuarine bayhead delta. Sedimentology 44: 263-286.

Olley JM, Pietsch T, Roberts RG. 2004. Optical dating of Holocene sediments from a variety of geomorphic settings using single grains of quartz. Geomorphology 60: 337-358.

Olsson IU. 1979. The importance of the pretreatment of wood and charcoal samples. In Radiocarbon Dating: Proceedings of the Ninth International Conference, Los Angeles and La Jolla, 1976, Berger R, Suess HE, University of California Press: Berkely, CA; $133-146$.

Roy PS. 1977. Does the Hunter River supply sand to the New South Wales coast today? Journal and Proceedings of the Royal Society of New South Wales 110: 17-24.

Roy PS, Thom BG. 1981. Late Quaternary marine deposition in New South Wales and southen Queensland—an evolutionary model. Journal of the Geological Society of Australia 28: 471-489.

Roy PS, Thom BG, Wright LD. 1980. Holocene sequences on an embayed high-energy coast: an evolutionary model. Sedimentary Geology 26: $1-19$. 
Roy PS, Williams RJ, Jones AR, Yassini I, Gibbs PJ, Coates B, West RJ, Scanes PR, Hudson JP, Nichol S. 2001. Structure and function of south-east Australian estuaries. Estuarine, Coastal and Shelf Science 53: 351-384.

Rustomji P. 2003. Holocene Geomorphology of the Macdonald and Tuross Rivers. PhD thesis, Australian National University.

Stanley DJ, Warne AG. 1994. Worldwide initiation of Holocene marine deltas by deceleration of sea-level rise. Science 265: $228-231$.

Stuiver M, Polach HA. 1977. Discussion: Reporting of ${ }^{14} \mathrm{C}$ data. Radiocarbon 19: $355-363$.

Stuiver M, Reimer PJ, Bard E, Beck JW, Burr GS, Hughen KA, Kromer B, McCormac G, van der Plicht J, Spurk M. 1998. INTCAL98 radiocarbon age calibration, 24,000-0 BP. Radiocarbon 40: 1041-1083.

Ta TKO, Nguyen VL, Tateishi M, Kobayashi I, Saito Y, Nakamura T. 2002. Sediment facies and late Holocene progradation of the Mekong River delta in Bentre Province, southern Vietnam: an example of evolution from tide-dominated to a tide- and wave-dominated delta. Sedimentary Geology 152: 313-325.

Thom BG, Roy PS. 1985. Relative sea levels and coastal sedimentation in southeast Australia in the Holocene. Journal of Sedimentary Petrology 55: 257-264.

Umitsu M, Buman M, Kawase K, Woodroffe CD. 2001. Holocene palaeoecology and formation of the Shoalhave River deltaic-estuarine plains, southeast Australia. The Holocene 11: 407-418.

Warner RF. 1987. The impacts of alternating flood- and drought-dominated regimes on channel morphology at Penrith, New South Wales, Australia. The Influence of Climate Change and Climatic Variability on the Hydrologic Regime and Water Resources, International Association of Hydrological Sciences Publication No. 168, 327-338.

Yang CT. 1973. Unit stream power and sediment transport. Journal of the Hydraulics Division, American Society of Civil Engineers HY10: $1805-1826$.

Young RW, White KL, Price DM. 1996. Fluvial deposition on the Shoalhaven Deltaic Plain, southern New South Wales. Australian Geographer 27: 215-234. 